\title{
EVALUATION OF LEISHMANIA ANTIGENS PREPARATION AND STORAGE FOR USE IN ENZYME IMMUNOASSAYS
}

\author{
Beatriz Julieta Celeste, Maria Carolina Soares Guimarães \\ and José Maria Pacheco de Souza
}

\begin{abstract}
The influence of time and temperature on the storage of an alkaline antigen of L.major-like and L.(V.) braziliensis promastigotes added or not of a proteases inbibitor (PMSF) was evaluted by means of an IgG-ELISA. Antibodies in assays using L. major-like antigen stored at $-20^{\circ} \mathrm{C}$ for 6 monsths had a statistically lower geometric mean titer (GMT) and different 95\% confidence interval limits (CL) than antigens stored otherwise, as assessed by the " $t$ " statistic. The PMSF L. major-like antigen after storage for 6 months at a temperature of $4^{\circ} \mathrm{C}$ had the same GMT and 95\% CL displayed at time zero as well as when storage for 4 and 6 months at $-20^{\circ} \mathrm{C}$. Significant diferences were not found when L.(V.) braziliensis antigens were stored at times and temperatures mentioned; the $P M S F$ antigen stored for 2 months at $-70^{\circ} \mathrm{C}$ resulted in a lower serum GMT and 95\% CL than any other, as assessed by the " $t$ " statistic. Antigen performance did not show any statistical difference associated to the addition of PMSF within the same species; the largest difference between antigens was that between PMSF-L. (V.) braziliensis and L. major-like without PMSF.
\end{abstract}

Key-words: Leishmania major-like. Leishmania (V.) braziliensis. Proteases inbibitor (PMSF). IgG-ELISA. Geometric mean titer.

One disadvantage of growing Leishmania $(V$.) braziliensis in liquid medium is its cost due to the need for addition of fetal calf serum to Schneider's Drosophila medium 12 . The same does not occur with L. major-like promastigotes which grow abundantly in culture media such as LIT (liver infusion tryptose) 4 a quality to be looked for when considering its use on mucocutaneous leishmaniasis seroepidemiology research where large quantities of parasites are needed; also, its use as antigen results in good performance indexes of sensitivity, specificity and positive predictive value on IFI tests, IgGELISA and Dot-ELISA2 8 10. L. major-like has been widely used for leishmaniasis seroepidemiologic research, mainly for IFI tests7 14 , but until this

\footnotetext{
Laboratório de Soroepidemiologia, Instituto de Medicina Tropical de São Paulo, Departamento de Medicina Preventiva, Faculdade de Medicina e Departamento de Epidemiologia, Faculdade de Saúde Pública da Universidade de São Paulo, São Paulo, SP.

Supported by LIM 38-Soroepidemiologia dos Laboratórios de Investigação Científica HC/FMUSP.

Address to: $\operatorname{Prof}^{\mathrm{a}} \mathrm{Dr}^{\mathrm{a}}$ Maria Carolina Soares Guimarães. Laboratório de Soroepidemiologia (LIM-38). Instituto de Medicina Tropical de São Paulo. Av. Dr. Eneas de Carvalho Aguiar 470, 05403-000 São Paulo, SP, Brasil. Fax: (011) 852-3622.

Recebido para publicação em 19/08/96.
}

moment its stability as antigen for any serology test had yet to be evaluated. The same happens with Leishmania (V.) braziliensis, although its use as antigen for seroepidemiological work has been much less than L. major-like's due to the difficulty for culturing the parasite as it grows poorly on liquid culture media in spite of the use of especially formulated products1.

The present report investigates the influence of time and temperature on the storage of alkaline extracts of $L$. major-like and $L$. (V.) braziliensis promastigotes and also the addition of PMSF by investigating their influence on the GMT of mucocutaneous leishmaniasis standard sera. The study on time and temperature was intended as a means to critically ascertain optimum storage and temperature for the antigens, an important step for serum surveys where the use of only one antigen batch is prefered. As proteases inhibitors 18 have been used in parasitic antigenic extracts in an attempt to minimize the action of proteolitic enzymes we thought interesting to critically evaluate its influence on the alkaline antigen performance by means of its influence on serum GMT.

\section{MATERIAL AND METHODS}

Sera. Twenty-nine positive standard sera were drawn from patients with a clinical 
Celeste BJ, Guimarães MCS, Souza JMP. Evaluation of Leishmania antigens preparation and storage for use in enzyme immunoassays. Revista da Sociedade Brasileira de Medicina Tropical 30:303-308, jul-ago, 1997.

diagnosis of mucocutaneous leishmaniasis and parasitology diagnosis by means of a Montenegro skin test 15 and ulcer imprint or biopsy33. Sera were drawn from male patients $(86.0 \%)$ and female $(13.8 \%), 7$ to 83 years of age. On previous assays sera had tested positive for anti-Leishmania IgG class antibodies by a $L$. major-like enzyme-linked immunoassay ELISA ${ }^{6}$ thirteen sera were drawn from in-patients at the Department of Dermatology, University of São Paulo Medical School, and 16 were drawn at regional offices of the Fundação Nacional de Saúde, Brazilian Ministry of Health. Twentytwo sera previously found to be negative for anti-Leishmania antibodies and antiTrypanosoma cruzi antibodies by IgGimmunofluorescence11 and IgG-Elisa, were used as negative controls.

All the sera had been previously diluted in an equal volume of glycerin $\mathrm{pH} 7.0$ and kept frozen at $-20^{\circ} \mathrm{C}$ until tested.

Antigens. Leishmania promastigotes used as antigen for IgG-ELISA tests were $L$. major-like (MHOM/BR/71/49) grown in LIT (liver infusion tryptose) culture medium 4 for 7 days at $25^{\circ} \mathrm{C}$ and $L$. (V.) braziliensis (MHOM/BR/ 75/M2903) grown in Schneider's Drosophila medium supplemented with $20 \%$ fetal calf serum, for 5 days at $25^{\circ} \mathrm{C} 1$.

Two antigens were prepared for each parasite species: one followed a preparation 6 , consisting of an alkaline promastigote extract and another consisting of the same alkaline extract to which $1 \mathrm{ul} \%$ of phenylmethane sulphonyl fluoride (PMSF) was added prior to cell disruption 16 .

Enzyme immunoassays. Wells of U-shapped microtiter plastic plates (Hemobag, Brazil) were filled with $100 \mathrm{ul}$ of $L$. major-like or $L$. $(V$.) braziliensis antigen at a protein concentration of $5 \mathrm{ug} / \mathrm{ml}$ in carbonate-bicarbonate buffer (0.06M, pH 9.6) and left overnight at $4^{\circ} \mathrm{C}$. For use, plates were drained and washed 3 times with PBST $(\mathrm{NaCl} 0.15 \mathrm{M}$; phosphates $0.01 \mathrm{M}$; pH 7.2; Tween-20 0.05\%). Sera were diluted twofold (starting dilution 1/40) with PBST, and $100 \mathrm{ul}$ of the dilution was added to each well. Plates were incubated at $37^{\circ} \mathrm{C}$ for 60 minutes and washed $3 \times 5$ minutes in PBST; wells were filled with 100 ul of an anti-IgG conjugate (gamma-chain specific) (Biolab, Brazil) diluted in PBST. The optimum dilution of conjugate and antigen had been determined previously by block titration in order to ensure maximum reactivity. Incubation proceeded for 60 minutes at room temperature followed by washings as described and 100ul of substrate (5.2mM 5-aminosalicylic acid, and $1.5 \mathrm{mM}$ $\mathrm{H}_{2} \mathrm{O}_{2}$ ) was added to each well17. Reaction was stopped by adding $25 \mathrm{ul}$ of $1 \mathrm{M} \mathrm{NaOH}$ to each well and the contents were read at a spectrophotometer using a $450 \mathrm{~nm}$ wavelength with the chromogen solution as blank.

Controls for ELISA consisted of the 22 standard negative sera, conjugate and antigen. The titration endpoint was taken as the absorbance greater than the average plus 2 standard deviations of the 22 negative sera.

Statistical analysis. For the assessment of geometric mean titers (GMT), all data were transformed into $\log (\mathrm{x}+1)$. Outcomes underwent variance analysis by Statgraphics 5.1. Significance level was 5\% for every statistical tests, adjustments been made for multiple tests. For the stability analysis of $L$. major-like and $L$. (V.) braziliensis when the null hypothesis (Ho) was rejected a Student "t" test for paired samples19 was done comparing the means obtained in different times and temperatures with the value obtained at zero time. To investigate the performance of the four antigen preparations the geometric means of each one at zero time were tested using the "t" statistic, adjusting significance level to 0.0125 (the quocient of $0.05 / 4,4$ representing 2 parasite species antigens prepared with and without PMSF).

\section{RESULTS}

Storage of $L$. major-like and $L$. (V.) braziliensis antigens at different times and temperatures resulted in statistically significant differences.

The GMT and 95\% CL for each time interval and storage temperature when $L$. major-like antigen was used is shown on Table 1 . There were no differnces in GMTs of any time intervals except when the antigen was stored at $-20^{\circ} \mathrm{C}$ for 6 months, a fact corroborated by the "t" statistics for that period ( $\mathrm{t}$ statistic $=2.96$, $\mathrm{t}$ critical $=2.83$ ). The addition of PMSF to the antigen resulted in significant decrease in serum GMT for antigen stored at $4^{\circ} \mathrm{C}$ for all time intervals considered $(\mathrm{t}$ statistic $=5.28$ for time interval 0-2 mo., -3.07 for time interval 04 mo. and -4.12 for time interval $0-6$ mo., $t$ critical $=2.83)$, for 6 months storage at $-20^{\circ} \mathrm{C}(\mathrm{t}$ statistic $=-4.68, \mathrm{t}$ critical $=-2.83))$. Differences in other time intervals and temperatures lacked statistical significance (Table 1). 
Celeste BJ, Guimarães MCS, Souza JMP. Evaluation of Leishmania antigens preparation and storage for use in enzyme immunoassays. Revista da Sociedade Brasileira de Medicina Tropical 30:303-308, jul-ago, 1997.

Table 1 - Geometric mean titer and 95\% confidence interval limits for IgG-ELISA and L. major-like antigen, added or not of PMSF stored at $4^{\circ} \mathrm{C},-20^{\circ} \mathrm{C}$ and $-70^{\circ} \mathrm{C}$ and tested after 2, 4 and 6 months.

\begin{tabular}{|c|c|c|c|c|c|c|c|c|}
\hline & & on PMSF-ad & d L. major & & & PMSF-ad & L. major-1 & \\
\hline time & 0 & 2 & 4 & 6 & 0 & 2 & 4 & 6 \\
\hline temp. & & & & & & & & \\
\hline room & $208 \mathrm{~b}$ & & & & 283 & & & \\
\hline temp. & $(161 ; 267)^{C}$ & & & & $(211 ; 381)$ & & & \\
\hline $4 \mathrm{OC}^{\circ}$ & & 268 & 192 & 156 & & 92 & 147 & 118 \\
\hline & & $(208 ; 345)$ & $(149 ; 247)$ & $(121 ; 200)$ & & $(68 ; 124)$ & $(109 ; 198)$ & $(87 ; 159)$ \\
\hline$-20^{\circ} \mathrm{C}$ & & 200 & 223 & 122 & & 297 & 178 & 104 \\
\hline & & $(156 ; 259)$ & $(173 ; 287)$ & $(94 ; 156)$ & & $(221 ; 400)$ & $(133 ; 240)$ & $(78 ; 141)$ \\
\hline$-70^{\circ} \mathrm{C}$ & & 213 & 133 & 281 & & 320 & 178 & 221 \\
\hline & & $(165 ; 274)$ & $(103 ; 171)$ & $(219 ; 362)$ & & $(237 ; 430)$ & $(133 ; 240)$ & $(165 ; 293)$ \\
\hline
\end{tabular}

$\mathrm{a}=$ time in months, $\mathrm{b}=$ geometric mean titer, $\mathrm{c}=95 \%$ confidence interval limits.

When the L. (V.) braziliensis antigen was used no statistically significant differences were seen on the GMT or the 95\% CL of standard sera at any time or temperature (Table 2). However, storage of the PMSF $L$. (V.) braziliensis for $0-2$ months at $-70^{\circ} \mathrm{C}$ resulted in a statistically significant lower serum GMT
(268) than at time zero $(\mathrm{GMT}=426)$ as Table 2 shows; the " $t$ " statistic was -3.34 for that time interval and storage temperature.

When antigen performance was analysed statistically significant differences in GMTs were seen. GMTs for L. major-like antigens were lower than those employing a $L .(V$.$) braziliensis antigen$

Table 2 - Geometric mean titer and 95\% confidence interval limits for IgG-ELISA with L. (V.) braziliensis antigen, added or not of PMSF stored at $4^{\circ} \mathrm{C},-20^{\circ} \mathrm{C}$ and $-70^{\circ} \mathrm{C}$ and tested after 2,4 and 6 months.

\begin{tabular}{|c|c|c|c|c|c|c|c|c|}
\hline & & oMSF-ac & d L.(V.)b. & & & PMSF & ded L.(V.)b & \\
\hline timea & 0 & 2 & 4 & 6 & 0 & 2 & 4 & 6 \\
\hline temp. & & & & & & & & \\
\hline room & $357 \mathrm{~b}$ & & & & 426 & & & \\
\hline temp. & $(273 ; 467)^{C}$ & & & & $(352 ; 516)$ & & & \\
\hline $4 \mathrm{OC}^{\circ}$ & & 262 & 216 & 250 & & 360 & 327 & 416 \\
\hline & & $(200 ; 345)$ & $(165 ; 283)$ & $(191 ; 326)$ & & $(297 ; 436)$ & $(270 ; 396)$ & $(343 ; 504)$ \\
\hline$-20^{\circ} \mathrm{C}$ & & 447 & 305 & 270 & & 469 & 369 & 369 \\
\hline & & $(341 ; 584)$ & $(233 ; 398)$ & $(207 ; 353)$ & & $(387 ; 568)$ & $(304 ; 447)$ & $(304 ; 447)$ \\
\hline$-70^{\circ} \mathrm{C}$ & & 258 & 262 & 268 & & 268 & 320 & 447 \\
\hline & & $(197 ; 337)$ & $(200 ; 342)$ & $(221 ; 325)$ & & $(221 ; 325)$ & $(264 ; 387)$ & $(369 ; 541)$ \\
\hline
\end{tabular}

$\mathrm{a}=$ time in months, $\mathrm{b}=$ geometric mean titer, $\mathrm{c}=95 \%$ confidence interval limits.

regardless of whether the antigens were added of PMS or not (Table 3); the "t" statistic for the interaction between antigens not added of PMSF was 3.73 and the "t" statistic for the interaction between antigens added of PMSF was 4.93 , critical $=2.63$.

The ability of either antigen to display the same standard serum titer was investigated. Serum titer agreement of $L$. major-like and PMSF L. major-like was 100.0\%; on assays using
L. (V.) braziliensis or PMSF L. (V.) braziliensis agreement was $96.5 \%$.

Serum titer agreement on assays using PMSF L. (V.) braziliensis and PMSF L. major-like antigens was 93.1\%; with PMSF L. (V.) braziliensis and $L$. major-like was $75,8 \%$.

Statistical significance for all antigens was analysed by means of the "F" statistic. For all antigens the statistic displayed a "F" value

\begin{tabular}{lcc}
$\begin{array}{l}\text { Table } 3 \text { - Geometric mean titers and } \\
\text { not of PMSF tested at time zero. }\end{array}$ & non PMSF-added & \\
\hline Antigen & $208 \mathrm{a}$ & PMSF-added \\
\hline L. major-like & $(169 ; 255) \mathrm{b}$ & 262 \\
& 357 & $(213 ; 321)$ \\
L. (V.) braziliensis & $(291 ; 438)$ & 426 \\
& $(347 ; 522)$ \\
\hline
\end{tabular}


Celeste BJ, Guimarães MCS, Souza JMP. Evaluation of Leishmania antigens preparation and storage for use in enzyme immunoassays. Revista da Sociedade Brasileira de Medicina Tropical 30:303-308, jul-ago, 1997.

ranging between 31.36 to 2.90 (critical "F" = 1.93) and a $\mathrm{p}<0.0001$ except for the contrast between times and temperatures of the PMSF-added $L$. $(V$.$) braziliensis antigen which displayed a "F"$ statistic of 3.11 (higher than the critical "F" value) and a $\mathrm{p}=0.0014$

\section{DISCUSSION}

Although used for many years for use in IgG-ELISA of mucocutaneous leishmaniasis serology the alkaline antigen of $L$. major-like had yet to be critically evaluated. Therefore, the design of this experiment and its statistical analysis were directed towards answering if differences could be found when two parasite antigens prepared in two different ways were stored for up to 6 months at different temperatures. Very often seroepidemiology of mucocutaneous leishmaniasis use as antigen for labelled antibody tests, a parasite easier to cultivate, presenting a lesser production cost such as L. major-like and not the actual etiological agent of mucocutaneous leishmaniasis, i.e., L. (V.) braziliensis 9 10. However, no investigation had yet been directed towards a thorough investigation on the ability of $L$. major-like to disclose the full range of antibodies synthetized in response to infection due to $L$. $(V$.) braziliensis. The null hypothesis for this investigation was that no differences could be observed on GMTs of standard mucocutaneous leishmaniasis sera when either antigen was used at any of the chosen storage periods and temperatures. For the L. major-like antigen only one storage time at $-20^{\circ} \mathrm{C}$ for 6 months had a significant difference from others as assessed by the "t" statistic. For the PMSF L. major-like antigen only those samples stored at $-70^{\circ} \mathrm{C}$ for the whole length of the experiment displayed non-significant differences according to the " $\mathrm{t}$ " statistic.

No statistical differences in GMT were observed for any of the storage periods or temperatures were those using the $L$. (V.) braziliensis antigen without addition of PMSF (Table 2). The addition of a proteases inhibitor to this antigen resulted on a fairly stable reagent except for storage at $-70^{\circ} \mathrm{C}$ for 2 months (Table 2); at the present time we have no explanation for this.

Another aspect of the statistical analysis regarded the performance of the antigens themselves. No statistical differences due to the addition of the proteases inhibitor PMSF were found on the performance of antigens of the same leishmania species, i.e. when the interaction between addition of PMSF or not to either L. major-like or $L$. (V.) braziliensis antigen but statistically significant differences were seen between L. major-like and L. (V.) braziliensis added of PMSF or not (Table 3). This is in disagreement with data reported by Guimarães et al.10, when analysing standard positive sera for mucocutaneous leishmaniasis by means of an IgG-IF test; the performance indices of tests employing a L. major-like or a L. (V.) braziliensis antigen did not show statistically significant differences on the capacity of the antigens to disclose anti-leishmania antibodies as assessed by the kappa statistic. The same was seen in a survey employing PMSF-L. major-like and $L$. (V.) braziliensis antigens in IgG-ELISA of Nicaraguan sera2; the "t" statistic did not show any difference on the ability of either antigen to disclose IgG class antibodies 2 but neither research work was designed to critically analyse the performance of different types of antigens as the present work was; their scope was to assess diagnostic performance indexes only.

According to the findings presented here the L. (V.) braziliensis was shown to be the best antigen for IgG-ELISA. However, this does not rule out $L$. major-like antigen use for seroepidemiological work in view of the low cost for growing promastigotes in LIT culture added to the fact that it priduces a very high promastigote yield. Growing leishmania in Schneider's Drosofilla medium is expensive due to the need of using fetal calf serum and introduces the use of a biological reagent of which availability is often difficult. These topics must be taken into account if a large scale survey work is intended as they may represent a significant amount of the total research budget.

The findings reported here suggest that the optimum storage period and temperature for $L$. (V.) braziliensis antigens would be $-20^{\circ} \mathrm{C}$ for 6 months and for L. major-like the optimum conditions seem to be storage at $-70^{\circ} \mathrm{C}$ for up to 6 months.

\section{RESUMO}

A influência do tempo e temperatura de estocagem de antígenos alcalinos de promastigotas de L. major-like e $\mathrm{L}$. (V.) braziliensis adicionados ou não de um inibidor de proteases foi avaliada por 
Celeste BJ, Guimarães MCS, Souza JMP. Evaluation of Leishmania antigens preparation and storage for use in enzyme immunoassays. Revista da Sociedade Brasileira de Medicina Tropical 30:303-308, jul-ago, 1997.

meio de reações de IgG-ELISA. A reação que empregava o antigeno de L. major-like estocado por 6 meses a $-20^{\circ} \mathrm{C}$ mostrou que médias geométricas dos títulos (MGT)e intervalos de confiança 95\% (IC 95\%) eram estatisticamente inferiores àquelas obtidas com antígenos estocados em outros intervalos de tempo, medido pela estatística " $t$ ". O antígeno PMSF-L. major-like depois de 6 meses de estocagem à temperatura de 40C tinha a mesma MGT e IC 95\% do tempo zero assim como quando ele foi estocado $a-20^{\circ} \mathrm{C}$ por 4 e 6 meses. Não foram observadas diferenças estatisticamente diferentes com os antigenos de L. (V.) braziliensis estocados nas mesmas condições de tempo e temperatura exceto o antígeno PMSF estocado por 2 meses a $-70^{\circ} \mathrm{C}$ que apresentou MGT e IC 95\% inferiores a quaisquer outras como aferido pela estatísitca " $t$ ". Quando comparados os desempenhos dos antígenos não houve direrenças estatisticamente significantes entre a adição ou não de PMSF para qualquer dos parasitas. A análise do cruzamento entre antígenos mostrou que a maior diferença netre eles foi a do contraste entre L. (V.) braziliensis adicionado de PMSF e L. major-like sem adição de PMSF.

Palavras-chaves: Leishmania major-like. Leishmania (V.) braziliensis. Inibidor de proteases (PMSF). IgG-ELISA. Média geométrica de títulos.

\section{REFERENCES}

1. Celeste BJ, Guimarães MCS. Growth curves of Leishmania braziliensis braziliensis promastigotes and surface antigen expression before and after adaptation to Schneider's Drosophila medium as assessed by anti-Leishmania human sera. Revista do Instituto de Medicina Tropical de São Paulo 30:63-67, 1988.

2. Corrales LEM. Soroepidemiologia da leishmaniose mucocutânea: comparação do desempenho dos antígenos de L. majorlike e Leishmania braziliensis braziliensis no teste ELISA para detecção de anticorpos de classe $\mathrm{G}$ e $\mathrm{M}$ em soros de pacientes da Nicarágua.Tese de mestrado,. Instituto de Ciências Biomédicas, Universidade de São Paulo. São Paulo, SP, 1992.

3. Cuba Cuba CA, Marsden PD, Barreto AC, Rocha R, Sampaio RR, Patzlaff L. Parasitologic and immunologic diagnosis of American (mucocutaneous) leishmaniasis. Bulletin of the Pan American Health Organization 15:249-249, 1981.

4. Fernandes JF, Castellani O. Grown characteristics and chemical composition of Trypanosoma cruzi. Experimental Parasitology 18:195-202, 1966.
5. Guimarães MCS, Celeste BJ, Camargo ME, Diniz JMP. Seroepidemiology of cutaneous leishmaniasis from Ribeira do Iguape Valley IgM and IgG antibodies detected by means of an immunoenzymatic assay (ELISA). Revista do Instituto de Medicina Tropical de São Paulo 25:99-108, 1983.

6. Guimarães MCS, Celeste BJ, Castilho EA, Mineo JR, Diniz JMP. Immunoenzymatic assay (ELISA) in mucocutaneous leishmaniasis, Kalazar and Chagas' disease: an epimastigote Trypanosoma cruzi antigen able to distinguish between antitrypanosoma and anti-leishmania antibodies. The American Journal of Tropical Medicine and Hygiene 30:942-947, 1981.

7. Guimarães MCS, Giovannini VL, Camargo ME. Antigenic standardization for mucocutaneous leishmaniasis immunofluorescence test. Revista do Instituto de Medicina Tropical de São Paulo 16:145-148, 1974 .

8. Guimarães MCS, Celeste BJ, Franco EL. Evaluation of Dot-Enzyme-Linked Immunosorbent Assay for mucocutaneous leishmaniasis and comparison with microplate enzyme-immunoassay. Journal of Clinical Microbiology 24:364-367, 1986.

9. Guimarães MCS, Celeste BJ, Franco EL. Diagnostic performance indices for immunofluorescent tets and enzyme immunoassays of leishmaniasis sera from Northern and Northeastern Brazil. Bulletin of the World Health Organization 68:39-43, 1990.

10. Guimarães MCS, Celeste BJ, Franco EL, Cucé LC, Belda Jr W. Evaluation of serological diagnostic indices for mucocutaneous leishmaniasis: immunofluorescence tests and Enzyme-Linked immunoassays for IgG, IgM and IgA antibodies. Bulletin of the World Health Organization 67:643648, 1989.

11. Guimarães MCS, Celeste BJ, Corrales LEM, Antunes CMF. Comparison on the performance of Leishmania major-like and Leishmania braziliensis braziliensis as antigen for New World leishmaniasis IgG immunofluoresscent test. Revista do Instituto de Medicina Tropical de São Paulo 33:503-508, 1991.

12. Hendricks LD, Wright N. Diagnosis of cutaneous leishmaniasis by in vitro cultivation of saline aspirates in Schneider's Drosophila Medium. The American Journal Tropical Medicine and Hygiene 28:962-964, 1979.

13. Marzochi MCA, Coutinho SG, Sabroza PC, Souza WJS. Reação de Imunofluorescencia indireta e intradermoreação para leishmaniose tegumentar 
Celeste BJ, Guimarães MCS, Souza JMP. Evaluation of Leishmania antigens preparation and storage for use in enzyme immunoassays. Revista da Sociedade Brasileira de Medicina Tropical 30:303-308, jul-ago, 1997.

americana em moradores na área de Jacarepaguá (Rio de Janeiro). Estudo comparativo dos resultados observados em 1974 e 1978. Revista do Instituto de Medicina Tropical de São Paulo 22:149-155, 1980.

14.Mendonça SCF, Souza WJS, Nunes MP, Marzochi MCA, Coutinho SG. Indirect immunofluorescence test in New World leishmaniasis: serological and clinical relationship. Memórias do Instituto Oswaldo Cruz, Rio de Janeiro 83:347-355, 1988.

15. Montenegro J. Cutaneous reaction in leishmaniasis. Anais da Faculdade de Medicina da Universidade de São Paulo 1:323-30, 1926.

16. North MJ, Mottran JC, Coombs GH. Cysteine proteinase of parasitic protozoa. Parasitology Today 6:270-275, 1990.
17. Riuntenberg EJ, Ljungstrom I, Sterenberg PA, Buys J. Application of immunofluorescence and immunoenzyme methods in the serodiagnosis of T. spiralis infection. Annals New York Academy of Sciences 254: 296-303, 1975.

18. Strych W, Miettinen A, Lottspeich F, Heidrich HG. Isolation and characterization of the $\mathbf{8 0 0 0 0}$ dalton Plasmodium falciparum merozoite surface antigen. Parasitology Research 73:435-441, 1987.

19. White C. Statistical methods in serum surveys. In: Paul JR, White C. Serological epidemiology. Academic Press, London, p. 19-33, 1973. 